\title{
Could mesenchymal stem cell therapy help in the treatment of muscle damage caused by Bothrops alternatus venom?
}

\author{
Thalita da Costa Telles ${ }^{1}$ Ana Flávia Machado Botelho ${ }^{1}$ Ana Luisa Soares de Miranda ${ }^{1}$ \\ Benito Soto-Blanco $^{1}$ Rogéria Serakides $^{1}$ Natália de Melo Ocarino $^{1}$ Marília Martins Melo $^{{ }^{*}}$
}

'Departamento de Clínica e Cirurgia Veterinárias, Universidade Federal de Minas Gerais (UFMG), Avenida Antônio Carlos, 6626, 31270-901, Belo Horizonte, MG, Brasil. E-mail: mariliamm@ufmg.br. "Corresponding author.

\begin{abstract}
The aim of this study was to evaluate the use of mesenchymal stem cells (MSC) in the treatment of myonecrosis induced by Bothrops alternatus venom in rats. Seventy-five male adult Wistar rats were divided into three experimental groups. G1 and G2 were injected in the gastrocnemius muscle with $120 \mu \mathrm{g}$ of B. alternatus venom, while G3 received $200 \mu \mathrm{L}$ of PBS only. Three days after the venom injection, 12 rats from G1 were treated with $5.0 \times 10^{6}$ MSC in PBS, whereas G2 and G3 rats received PBS. Every three days, blood and muscle samples of five animals from each group were taken for serum biochemical and pathological analyses. Histological examinations showed more intense muscle lesions following MSC treatment, characterized by disorganization and loss of muscle fibers, with focal necrosis and inflammatory infiltration by mononuclear cells. In conclusion, the use of MSC for the treatment of local damage caused by inoculation of B. alternatus venom impaired muscle regeneration and interfered in the healing process.
\end{abstract}

Key words: Viperidae envenomation, stem cells, rats, myonecrosis, muscular repair.

Podem as células tronco mesenquimais auxiliarem no tratamento da lesão muscular causada pelo veneno de Bothrops alternatus?

RESUMO: $O$ objetivo do presente trabalho foi avaliar a utilização das células tronco mesenquimais (MSC) no tratamento da mionecrose induzida pelo veneno de Bothrops alternatus em ratos. 75 ratos Wistar adultos foram distribuidos em três grupos experimentais. G1 e G2 receberam $120 \mu \mathrm{g}$ de veneno de B. alternatus, enquanto o G3 recebeu apenas $200 \mu L$ de PBS. Três dias após a administração do veneno, os ratos do grupo $G 1$ foram tratados com $5.0 \times 10^{6} \mathrm{MSC}$, enquanto G2 e G3 receberam exclusivamente PBS. A cada três dias, amostras de sangue e tecido muscular foram coletadas de cinco animais de cada grupo para avaliação bioquímica sérica e patológica, respectivamente. A análise histológica revelou lesão muscular mais intensa após a aplicação das MSC, caracterizada pela desorganização e perdas das fibras musculares, com necrose focal e infiltrado inflamatório mononuclear. É possível concluir que a utilização das MSC para o tratamento da lesão local causada pela inoculação do veneno B. alternatus deteriorou a regeneração muscular e interferiu com o processo de cicatrização. Palavras-chave: envenenamento por cobra, células tronco, ratos, mionecrose, reparação muscular.

The venom of Bothrops alternatus Duméril, Bibron \& e Duméril, snake has myotoxic, proteolytic, and coagulant activities that can be lethal, due to the presence of metalloproteinases (SVMP) and myotoxic phospholipases $\mathrm{A}_{2}\left(\mathrm{PLA}_{2}\right)$. The standard treatment for these cases is the immediate administration of antibothropic antivenom; however, it can only partially neutralize local effects of the toxins and continuous research has been conducted to complement this therapy (MELO et al., 2005). One possible complementary therapy for Bothrops envenomation is the local injection of mesenchymal stem cells (MSC) that could improve muscle repair due to their regenerative ability and differentiation capability. In fact, stem cells are known to have potential to differentiate into myocytes and promote tendon and muscle repair (DAVIES et al., 2013). In view of the severity of local lesions caused by bothropic envenomation, which often leads to permanent tissue damage, new therapy options are important to provide complementary treatment to antivenom application. This study aimed to evaluate 
the ability of MSC to promote muscle regeneration in rats after injection of $B$. alternatus venom.

Three 30-day-old female Wistar rats (Rattus norvegicus) were euthanized to obtain bone marrow stem cell cultures as previously described (OCARINO et al., 2010). The MSC were analyzed using a FAC Scan cytometer (Becton Dickinson, Mountain View, USA) and data were analyzed using Cell quest software (Becton Dickinson). Evaluation of the phenotypic characterization of MSC, derived from bone marrow tissue, indicated the expression of CD90 (clone 0x-75 mouse), CD73 (clone $5 \mathrm{~F} /$ B9 mouse), and CD54 (clone 1A29 mouse) in $86.8 \%, 94.0 \%$, and $95.1 \%$ of the cells, respectively, while CD45 was not expressed in $97.0 \%$ of the cells confirming its classification. After phenotypic characterization and immediately before injection, cellular viability was analyzed using trypan blue stain, showing $100 \%$ viability.

Crude venom was obtained from a collection of adult B. alternatus specimens from Minas Gerais State (Brazil). Immediately after collection, venom was dried in a vacuum desiccator at room temperature and kept frozen at $-20^{\circ} \mathrm{C}$ until use.

Seventy-five adult male Wistar rats weighing about $120 \mathrm{~g}$ were randomly divided into three groups: $\mathrm{G} 1(\mathrm{n}=25), \mathrm{G} 2(\mathrm{n}=25)$, and $\mathrm{G} 3(\mathrm{n}=25)$. Rats from $\mathrm{G} 1$ and $\mathrm{G} 2$ received an intramuscular (i.m.) injection of $120 \mu \mathrm{g}$ of $B$. alternatus venom dissolved in $200 \mu \mathrm{L}$ of phosphate buffered saline (PBS), while G3 received $200 \mu \mathrm{L}$ of PBS only. After $72 \mathrm{~h}$, G1 animals were treated with a single i.m. injection of $5 \times 10^{6}$ MSC diluted in $200 \mu \mathrm{L}$ of PBS (at the venom injection site), while G2 (positive control) and G3 (negative control) received $200 \mu \mathrm{L}$ of PBS.

Blood samples were obtained from cardiac puncture of five animals from each group on the $3^{\text {rd }}, 6^{\text {th }}$, $9^{\text {th }}, 12^{\text {th }}$, and $15^{\text {th }}$ days following treatment, to perform biochemical analysis by kinetic assay (TP Analyzer Basic, Thermoplate, São Paulo, PS, Brazil). Before each blood sampling, animals were anesthetized with an i.m. injection of $10 \mathrm{mg} / \mathrm{kg}$ of xylazine hydrochloride and $75 \mathrm{mg} / \mathrm{kg}$ of ketamine (Sigma-Aldrich, St. Louis, USA). Blood samples were stored in blood flasks without anti-coagulant to obtain sera to measure the activities of creatine kinase $(\mathrm{CK})$, aspartate aminotransferase (AST), and lactate dehydrogenase (LDH) (Bioclin, Belo Horizonte, MG, Brazil). Immediately after each blood collection, these five animals from each group were euthanized. Samples from gastrocnemius muscles were processed by paraffin histological technique and stained with Hematoxylin-eosin (HE) and Masson's Trichrome stain (MT).
All statistical analyses were performed using Statistical Software SAS (Cary, NC, USA). Data were analyzed by the Lillifors, KolmogorovSmirnov and Shapiro-Wilk normality tests. Statistical differences were detected by analysis of variance (ANOVA) followed by SNK test at $P<0.05$.

Both envenomed groups presented high CK values when compared to control rats. Animals treated with MSC showed higher activities all moments; although, a significant decrease occurred after nine days, as with the positive control group. LDH activities were also higher inG1 rats than in G3. AST values showed variations between all groups only on the $3^{\text {rd }}$ day, with highest activities in G1 and lowest in G3.

No macroscopic signs of dermonecrosis and blistering were observed in all groups. Microscopic evaluation of the control group (G3) revealed mild microscopic focal inflammation only after 3 days. Muscle samples from envenomed rats treated with MSC (G1) and PBS (G2) presented similar changes. Animals that received MSC presented more lesions, especially on the $3^{\text {rd }}$ day. After 6 days, both envenomed groups presented partial loss of muscle fibers associated with disorganization of the bundles and focal necrosis with mononuclear cells (macrophages) and fibroblasts. Mild focal hemorrhage and few neutrophils were seen. The same lesion points were evaluated through Masson's Trichrome stain showing large areas of connective tissue with no difference in the extension of the lesions or collagen content. After 6 days, both envenomed groups presented disorganized muscle fibers with few macrophages and central nuclei myocytes. After 9 days, a mild and gradual decrease of lesion areas was observed, continuing until the $15^{\text {th }}$ day.

The limitations of the antivenom therapy in the treatment of myonecrosis prompted the search for new therapy options and one hypothesis would be the use of MSC as an alternative to overcome such local lesions. Previous studies that evaluated stem cells as a successful treatment option for muscle injury used different animal models than in this study (PECANHA et al., 2012). However, this is the first study to evaluate the potential of such cells in lesions caused by $B$. alternatus venom.

Regeneration therapy with MSC is considered promising and has raised hope for faster healing of severe musculoskeletal injuries (DAVIES et al., 2013). MSC used in this research expressed surface markers in accordance to previous studies (SCHAFFLER \& BUCHLER, 2007).

MSC were injected at the site of inoculation after three days and samples were collected in the 
following 15 days to establish myonecrosis and ensure that the initial inflammatory process would not interfere with the MSC. This delayed treatment showed no potential inhibition of the proteolytic, hemorrhagic, and myonecrotic activity of $B$. alternatus venom. It also did not affect fibrosis as previously reported (PECANHA et al., 2012).

Animals treated with MSC (G1) showed a significant increase of CK, AST, and LDH levels, presenting a similar pathophysiology with other snakes from the Bothrops complex (CHAVES et al., 1989).

Myotoxic activity was also assessed based on histological results. The venom led to cell disorganization, loss of the arrangements of skeletal fibers, mild hemorrhage, focal necrosis, and mild infiltration of inflammatory cells, predominantly mononuclear cells (macrophages) (VOMERO et al., 2009). Animals treated with MSC presented more lesions, especially in the $3^{\text {rd }}$ day, which also correlates with CK serum results. Masson's Trichrome stain showed large areas of connective tissue with no difference in the extension of the lesions or collagen content (LOPES et al., 2012). These results are in agreement with the observed serum markers increase, which occurs early in the course of envenoming.

Mild hemorrhage associated with muscle necrosis, unchanged fibrosis, and high activities of $\mathrm{CK}$, AST, and LDH after MSC treatment suggests these cells can aggravate muscular damage caused by the venom and may disrupt muscle regeneration. It is possible that the injection of pluripotent cells can exert pro inflammatory effects within the following days of inoculation (MARIGO \& DAZZI, 2011). Previous research using MSC therapy indicated that its inflammatory response depends on the microenvironment, exerting anti or proinflammatory responses according to cytokines expressions and local immunomodulatory cells (KIM \& CHO, 2013). Toxic components of bothropic venom can also cause severe damage to microvasculature, especially metalloproteinases and phospholipases. Vascular impairment associated with necrosis, hemorrhage, and coagulant disturbances may provide a micro environment unsuitable for the implantation and significant differentiation of MSC. A recent study using mice revealed intense muscular damage with hemorrhage and necrosis after B. alternatus venom injection. Lesions were fully regenerated without treatment after 28 days (GARCIA DENEGRI et al., 2016), and this outcome may result from differences in species sensibility.

In conclusion, the administration of MSC increases muscle damage and could impair local treatment of envenomation caused by $B$. alternatus venom. Our hypothesis remains open for future experimental testing.

\section{BIOETHICS AND BIOSSECURITY COMMITTEE APPROVAL}

All handling and experimental procedures with animals were approved by the Ethics Committee in Animal Experimentation, Universidade Federal de Minas Gerais (UFMG).

\section{ACKNOWLEDGEMENTS}

This research was financially supported by Conselho Nacional de Desenvolvimento Científico e Tecnológico (CNPq), Grant N.305462/2013-0.

\section{REFERENCES}

CHAVES, F. et al. Histopathological and biochemical alterations induced by intramuscular injection of Bothrops asper (terciopelo) venom in mice. Toxicon, v.27, p. 1085-1093, 1989. Available from: $<$ http://dx.doi.org/10.1016/0041-0101(89)90002-0>. Accessed: Jan. 15, 2017. doi: 10.1016/j.toxicon.2016.10.005.

DAVIES, B.M.et al. Repairing damaged tendon and muscle are mesenchymal stem cells and scaffolds the answer? Regenerative Medicine, v.8, p.613-630, 2013. Available from: $<$ http://dx.doi.org/10.2217/rme.13.55>. Accessed: Sept. 10, 2017. doi: $10.2217 /$ rme.13.55.

GARCIA DENEGRI, M.E. et al. Efficient muscle regeneration after highly hemorrhagic Bothrops alternatus venom injection. Toxicon, v.122, p.167-175, 2016. Available from: $<$ http://dx.doi org/10.1016/j.toxicon.2016.10.005>. Accessed: Jan. 15, 2017. doi: 10.1016/j.toxicon.2016.10.005

KIM, N.; CHO, S.G. Clinical applications of mesenchymal stem cells. The Korean Journal of Internal Medicine, v.28, p.387-402, 2013. Available from: <http:/dx.doi.org/10.3904/kjim.2013.28.4.387>. Accessed: Dec. 12, 2016. doi: 10.3904/kjim.2013.28.4.387.

LOPES J.A. et al. Intradermal injection of Bothrops cotiara venom in mice in an experimental wound model. Journal of Venoms Animals Toxins Including Tropical Diseases, v.18, p.73-82, 2012. Available from: <http://dx.doi.org/10.1590/S1678-91992012000100009>. Accessed: Nov. 10, 2016. doi: 10.1590/S1678-91992012000100009.

MARIGO, I.; DAZZI, F. The immunomodulatory properties of mesenchymal stem cells. Seminars in Immunopathology, v.33, p.593-602, 2011. Available from: $<$ https://doi.org/10.1007/s00281011-0267-7>. Accessed: Dec. 12, 2016.

MELO, M.M. et al. Treatment of Bothrops alternatus envenomation by Curcuma longa and Calendula offinalis extracts and ar-tumerone. Arquivo Brasileiro de Medicina Veterinária e Zootecnia, v.57, p.7-17, 2005. Available from: <http://dx.doi. org/10.1590/S0102-09352005000100002>. Accessed: Jan. 04, 2017. doi: 10.1590/S0102-09352005000100002.

OCARINO, N.M. et al. Intra-bone marrow injection of mesenchymal stem cells improves femur bone mass of osteoporotic female rats. Connective Tissue Research, v.51, p.426-433, 2010. 
Available from: <http://dx.doi.org/10.3109/03008201003597049>. Accessed: Oct. 10, 2016. doi: 10.3109/03008201003597049.

PECANHA, R. et al. Adipose-derived stem-cell treatment of skeletal muscle injury. The Journal of Bone and Joint Surgery, v.94, p.609 617, 2012. Available from: <http://dx.doi.org/10.2106/JBJS.K.00351>. Accessed: Sept. 10, 2017. doi: 10.2106/JBJS.K.00351.

SCHAFFLER, A.; BUCHLER, C. Concise review: Adipose tissuederived stromal cells - basic and clinical implications for novel cell-based therapies. Stem Cells, v.25, p.818-827, 2007. Available from: $<$ http://dx.doi.org/10.1634/stemcells.2006-0589>. Accessed: Nov. 10, 2016. doi: 10.1634/stemcells.2006-0589.

VOMERO, V.U. et al. Treatment with an anti-inflammatory drug is detrimental for muscle regeneration at Bothrops jararacussu envenoming: an experimental study. Toxicon, v.54, p.361363, 2009. Available from: <http://dx.doi.org/10.1016/j. toxicon.2009.04.006>. Accessed: Dec. 12, 2016. doi: 10.1016/j. toxicon.2009.04.006. 